\title{
Suspect feline infectious peritonitis pada kucing
}

\author{
Sus Derthi Widhyari ${ }^{1}{ }^{*}$, Bayu Firmala Kusuma ${ }^{2}$, Setyo Widodo ${ }^{1}$, Anita Esfandiari ${ }^{1}$, \\ Retno Wulansari ${ }^{1}$, Leni Maylina ${ }^{1}$ \\ ${ }^{1}$ Departemen Klinik Reproduksi dan Patologi, Fakultas Kedokteran Hewan, Institut Pertanian Bogor, Bogor \\ ${ }^{2}$ Program Pendidikan Profesi Dokter Hewan, Fakultas Kedokteran Hewan, Institut Pertanian Bogor, Bogor
}

ABSTRAK: Feline infectious peritonitis (FIP) adalah penyakit menular akibat infeksi corona virus dan dapat berakibat
kematian. Diagnosa FIP dijumpai pada seekor kucing dengan gejala anoreksia, lemas, perut membesar dan diare. Hasil
pemeriksaan abdomen menunjukkan adanya undulasi positif diduga akibat penimbunan cairan di rongga abdomen. FIP tipe ini
dijumpai adanya akumulasi cairan dalam rongga perut dan menyebabkan terjadinya pembesaran daerah abdomen dan disertai
kesulitan bernafas. Berdasarkan pemeriksaan klinis dan laboratories, kucing di diagnosa mengalami suspect Feline Infectious
Peritonitis (FIP) tipe basah. Perlu dilakukan pemeriksaan penunjang untuk lebih meneguhkan diagnosa, seperti uji serologis,
radiografi, dan ultrasonografi.
Kata kunci:
feline infectious peritonitis, pembesaran abdomen, kucing

\section{- PENDAHULUAN}

Feline Infectious Peritonitis (FIP) merupakan penyakit yang disebabkan oleh coronavirus (FCoV) yang dapat menyebabkan gangguan respirasi akut atau enteritis pada kucing (Pedersen 2014). Jenis coronavirus yang sering menyerang kucing disebabkan oleh Feline Enteric Coronavirus (FECV). Virus ini relatif tidak berbahaya, akan tetapi FECV dapat bermutasi menjadi virus ganas yang dapat berakibat kematian. Virus ini dikenal sebagai penyebab FIP yaitu Feline Infectious Peritonitis Virus (FIPV).

FECV adalah virus umum yang sering menyerang kucing dan dapat menular. FECV bereplikasi terutama di sel epitel usus dan dikeluarkan bersama tinja. Sedangkan virus FIPV bereplikasi di dalam sel makrofag dan sel monosit. Penyakit yang disebabkan oleh virus ini umumnya menyerang kucing pada umur sekitar 4 bulan sampai umur 3 tahun (Bell et al. 2006, Pedersen 2014).

Manifestasi FIP dibagi ke dalam 2 bentuk, yaitu tipe basah dan kering. Kedua tipe memiliki gejala demam, anoreksia, kehilangan bobot badan, dan letargi. Tipe basah dicirikan oleh adanya akumulasi cairan di dalam rongga abdomen, rongga dada, atau keduanya. Kucing yang rongga dadanya terakumulasi cairan menyebabkan sulit bernafas, sedangkan kucing dengan cairan dalam rongga abdomen menunjukkan adanya pembesaran abdomen secara progresif. Penyakit tipe basah ini berjalan cepat dan perut kucing akan membuncit karena penimbunan cairan di dalam dada dan perut (Hartmann et al. 2003). Penularan virus coronavirus umumnya melalui per oral. Virus akan bereplikasi pada epitel usus halus menimbulkan kerusakan pada epitel mukosa usus halus sehingga menimbulkan diare (Kipar et al. 2010). Beberapa kasus memiliki gejala klinis yang memiliki kemiripan dengan gejala pada penyakit lain.

\section{- SINYALEMEN DAN TEMUAN KLINIS}

Sinyalemen: Seekor kucing domestik jantan dewasa steril berumur 3 tahun bernama Lapet. Temuan klinis: Kucing Lapet dalam keadaan anoreksia, lemas, perut membesar, diare, mudah stres, dan mengalami penurunan bobot badan. Bobot badannya $3.6 \mathrm{~kg}$. Suhu tubuh kucing pada saat pemeriksaan adalah $38.4{ }^{\circ} \mathrm{C}$ dengan frekuensi nadi 120 kali per menit dan frekuensi nafas 22 kali per menit. Terdapat undulasi positif diduga akibat penimbunan cairan di rongga abdomen. Berdasarkan pemeriksaan klinis pada kucing Lapet, secara umum tidak ditemukan adanya kelainan pada sistem integumen, genitalia, kardiovaskular/sirkulasi, dan lokomosi.

\section{- HASIL DAN PEMBAHASAN}

Hasil pemeriksaan hematologi kucing ini menunjukkan hasil yang normal, tidak ditemukan kelainan yang berarti (Tabel 1). Menurut Pedersen et al. (2008), kucing yang mengalami ascites dicirikan lymphopenia dengan nilai $<1500 / \mu \mathrm{L}$ dan anemia. Sedangkan menurut Hirschberger et al. (1995) pada pemeriksaan serum ditemukan rasio albumin:globulin $<0.6$, total serum globulin $>5.1 \mathrm{~g} / \mathrm{dL}$, hipoalbuminemia (kisaran normal 2.4-4.1 g/dL), peningkatan enzim hati, azotemia, hiperbilirubinemia, dan hiperbilirubinuria. Kasus ini tidak dilakukan pemeriksaan kimia darah dan cairan abdomen.

Diterima: 08-12-2017 | Direvisi: 09-01-2018 | Disetujui: 30-01-2018 (C) 2018 CC-BY-SA. Ini adalah artikel Open Access yang didistribusikan berdasarkan ketentuan dari Creative Commons Attribution ShareAlike 4.0 Inter national License (https://creativecommons.org/licenses/by-sa/4.0/). 
Feline Infectious Peritonitis bentuk basah (effusive) lebih umum terjadi dari pada bentuk kering (non-effusive). Penumpukan cairan berwarna kekuningan yang mengandung protein dalam konsentrasi tinggi akibat adanya respon sistem imun. Hal ini dapat mengakibatkan terjadinya kerusakan dinding pembuluh darah kecil sehingga cairan keluar ke jaringan sekitarnya (Sparkes 2004)

Tabel 1 Hasil pemeriksaan hematologi kucing Lapet

\begin{tabular}{|lccc|}
\hline Pemeriksaan & Hasil & Satuan & Kisaran Normal \\
\hline WBC & 12.1 & $103 / \mu \mathrm{L}$ & $10.0-15.0$ \\
RBC & 8.6 & $10 \% \mu \mathrm{L}$ & $5.0-10.0$ \\
Hematokrit & 40 & $\%$ & $25.0-45.0$ \\
Hemoglobin & 13.4 & $\mathrm{~g} / \mathrm{dL}$ & $8.0-17.0$ \\
Limfosit & 33 & $\%$ & $30-35$ \\
Monosit & 5 & $\%$ & $5-6$ \\
Eosinofil & 2 & $\%$ & $2-5$ \\
Basofil & 1 & $\%$ & 1 \\
Seg. Netrofil & 56 & $\%$ & $55.0-60.0$ \\
Band Netrofil & 1 & $\%$ & $<5$ \\
\hline
\end{tabular}

Cairan bersifat transudat pada rongga abdomen (hidrops ascites) dapat berasal dari plasma yang berefusi dari pembuluh darah terutama akibat gangguan pada keseimbangan protein. Karakteristik cairan effusi yang muncul dari FIP tipe basah antara lain mucinous, berwarna kuning keemasan, agak keruh, lengket, bila dikocok akan berbusa, memiliki nilai berat jenis 1.017-1.047, dan mengandung protein tinggi $>3.5 \mathrm{~g} / \mathrm{dL}$ (Sparkes 2004). Menurut Hartmann et al. (2003) keberadaan efusi memudahkan diagnosis, karena tes pada efusi memiliki nilai diagnostik lebih tinggi daripada tes darah. Efusi FIP biasanya memiliki kandungan protein yang sangat tinggi (> $35 \mathrm{~g} / \mathrm{l}$ ) dan didominasi adanya sel peradangan seperti sel makrofag dan sel neutrofil.

Diagnosa FIP dapat melalui anamnesa, gejala klinis, pemeriksaan penunjang seperti pemeriksaan serologis, ultrasonografi, radiografi, dan analisis darah (kimia darah dan whole blood). Uji serologis dapat dilakukan dengan menggunakan test ELISA (Enzym linked immunosorbent assay) dan PCR metode Polymerase chain reaction (Pedersen 2014). Diagnosis FIP juga dapat dilakukan melalui test Rivalta. Tes ini dapat dilakukan dengan cara menggunakan beberapa tetes cairan abdomen ke dalam tabung yang sebelumnya telah diisi dengan larutan asam asetat lemah. Bahan flokulan yang muncul terlihat pada uji Rivalta menunjukkan bahwa tes dalah positif (Hartmann et al., 2003).

\section{- SIMPULAN}

Berdasarkan pemeriksaan klinis, kucing Lapet di diagnosa mengalami suspect Feline Infectious Peritonitis (FIP) tipe basah. Perlu dilakukan pemeriksaan penunjang untuk lebih meneguhkan diagnosa, seperti pemeriksaan serologis, kimia darah lengkap, pemeriksaan cairan effusi, radiografi, dan ultrasonografi.

\section{- INFORMASI PENULIS}

Penulis untuk korespondensi

*SDW: derthi64@gmail.com

Divisi Penyakit Dalam, Wing 2, Level 3

Departemen Klinik, Reproduksi dan Patologi,

Fakultas Kedokteran Hewan, Institut Pertanian Bogor, Bogor

Jl. Agatis Kampus IPB Dramaga Bogor 16680

\section{- UCAPAN TERIMA KASIH}

Terima kasih kepada Kelompok A-2 Program Pendidikan Profesi Dokter Hewan (PPDH) Tahun 2015.

\section{- PUSTAKA ACUAN}

Bell ET, Malik R, Norris JM. 2006. The relationship between the Feline Coronavirus antibody titre and the age, breed, gender and health status of Australia cats. Australian veterinary journal. 84(1-2): 2-7.

Hartmann K, Binder C, Hirschberger J, Cole D, Reinacher M, Schroo S, Frost J, Egberink H, Lutz H, Hermanns W. 2003. Comparison of different tests to diagnose feline infectious peritonitis. Journal of veterinary medicine. 17(6): 781-790.

Hirschberger J, Hartmann K, Wilhelm N, Frost J, Lutz H, Kraft W. 1995. Clinical symptoms and diagnosis of feline infectious peritonitis. Tierarztliche praxis. 23(1): 92-99.

Kipar A, Meli ML, Baptiste KE, Bowker LJ and Lutz H. 2010. Sites of feline coronavirus persistence in healthy cats. Journal of general virology. 91(7): 1698-1707.

Pedersen NC, Allen CE, Lyons LA. 2008. Pathogenesis of feline enteric coronavirus infection. Journal of feline medicine and surgery. 10(6): 529-541.

Pedersen NC. 2014. Understanding feline infectious peritonitis - An Interview with Niels C. Pedersen. p1-7. https://pdfs. semanticschlar.org/7077/d98dcc66190b78c7089cad9429466100 58c8.pdf

Sparkes AH. 2004. Feline Coronavirus Infectionin Cat. Chandler EA, Gaskell CJ, Gaskell RM (editor), Feline Medicine and Therapeutics.Edisi ke-3. Oxford: Blackwell Pub dan BSAVA. Hlm 623-636. 